\title{
Peritoneal fluid collection in healthy cattle and evaluation of changes in cell morphology during storage in refrigerated and non-refrigerated samples ${ }^{1}$
}

\author{
Nathali A.A. Sales ${ }^{2}$ D, Karina K.M.C. Flaiban ${ }^{3}$, Joandes H. Fonteque ${ }^{4}$ \\ and Júlio A.N. Lisbôa ${ }^{5 *}$ (D)
}

\begin{abstract}
Sales N.A.A., Flaiban K.K.M.C., Fonteque J.H. \& Lisbôa J.A.N. 2020. Peritoneal fluid collection in healthy cattle and evaluation of changes in cell morphology during storage in refrigerated and non-refrigerated samples. Pesquisa Veterinária Brasileira 40(3):158-164. Departamento de Clínicas Veterinárias, Centro de Ciências Agrárias, Universidade Estadual de Londrina, Campus Universitário, Cx. Postal 10011, Londrina, PR 86057-970, Brazil. E-mail: janlisboa@uel.br

This study aimed to evaluate the appropriate sites of abdominocentesis for peritoneal fluid collection in cattle and to investigate the time of cell viability in vitro, comparing three methods of sample conservation. Twenty-one healthy cattle (19 females and 2 males) were subjected to a laparocentesis procedure to obtain peritoneal fluid, with punctures in three defined sites: left cranial, right cranial, and right caudal. The total peritoneal fluid collected was divided into three aliquots and maintained under three preservation conditions: room temperature $\left(26^{\circ} \mathrm{C}\right)$, refrigeration $\left(4^{\circ} \mathrm{C}\right)$, and room temperature $\left(26^{\circ} \mathrm{C}\right)$ with the addition of $1 \mu \mathrm{L}$ of $10 \%$ formaldehyde per $1 \mathrm{~mL}$ of peritoneal fluid. The peritoneal fluid analysis performed immediately after collection consisted of: physical examination (color, appearance, volume, and specific gravity), biochemical measures ( $\mathrm{pH}$, total protein, fibrinogen, creatinine, and glucose), and cellularity (total and differential counts). The determination of proteins and the examination of cells were repeated in each separate aliquot at two, four, six, and eight hours after harvest. Data were analyzed through repeated measures ANOVA or Friedman test. The harvest was productive in $67 \%$ of cattle. The left cranial and the right cranial puncture sites were the most appropriate. Peritoneal fluid analyzed after collection, the total protein concentration ranged from 1.4 to $3.6 \mathrm{~g} / \mathrm{dL}$, and number of leukocytes ranged from 54 to 1,322 cells/ $\mu \mathrm{L} ; 60$ to $95 \%$ of leukocytes were lymphocytes. The protein concentration decreased, but the absolute values of leukocytes, lymphocytes, and segmented neutrophils did not change up to eight hours after collection, independent of the maintenance method. Cell lysis was delayed by cooling, and the addition of formaldehyde did not help preserve the integrity of cellular morphology. Laparocentesis is a safe and secure procedure in cattle and maybe more productive when performed in specific sites on the left or right sides of the cranial abdominal wall. Peritoneal fluid samples may be analyzed with reliable results for up to eight hours after collection when kept refrigerated and for up to six hours when kept at room temperature.
\end{abstract}

INDEX TERMS: Peritoneal fluid, healthy cattle, cell morphology, abdominocentesis, cell viability, conservation, cattle.

\footnotetext{
${ }^{1}$ Received on September 5, 2019.

Accepted for publication on September 23, 2019.

${ }^{2}$ Master's student in Animal Health and Production in the Tropics, Universidade de Uberaba, Av. Nenê Sabino 1801, Campus Universitário, Uberaba, MG 38055-500, Brazil.

${ }^{3}$ Departamento de Medicina Veterinária Preventiva, Centro de Ciências Agrárias, Universidade Estadual de Londrina (UEL), Campus Universitário, Rodovia Celso Garcia Cid PR-445 Km 380, Cx. Postal 10011, Londrina, PR 86057-970, Brazil.
}

\footnotetext{
${ }^{4}$ Departamento de Medicina Veterinária, Centro de Ciências Agroveterinárias, Universidade do Estado de Santa Catarina (UDESC), Av. Luiz de Camões 2090, Bairro Conta Dinheiro, Lages, SC 88520-000, Brazil.

${ }^{5}$ Departamento de Clínicas Veterinárias, Centro de Ciências Agrárias, Universidade Estadual de Londrina (UEL), Rodovia Celso Garcia Cid PR445 Km 380, Cx. Postal 10011, Londrina, PR 86057-970. *Corresponding author: janlisboa@uel.br
} 
RESUMO.- [Colheita do fluido peritoneal de bovinos
sadios e verificação das alterações na morfologia celular
quando mantido refrigerado ou à temperatura ambiente.] quando mantido refrigerado ou à temperatura ambiente.] laparocentese para a colheita de fluido peritoneal de bovinos e estabelecer o tempo de viabilidade celular in vitro, comparando três métodos de conservação. Vinte e um bovinos hígidos (19 fêmeas e 2 machos) foram submetidos ao procedimento de laparocentese para obtenção de fluido peritoneal, com punção em três pontos definidos: cranial esquerdo, cranial direito e caudal direito. 0 volume total do líquido peritoneal foi dividido em três alíquotas mantidas sob três métodos de conservação: temperatura ambiente $\left(26^{\circ} \mathrm{C}\right)$; refrigeração $\left(4^{\circ} \mathrm{C}\right)$; e temperatura ambiente $\left(26^{\circ} \mathrm{C}\right)$ com adição de $1 \mu \mathrm{L}$ de formol $10 \%$ para cada $1 \mathrm{~mL}$ de líquido peritonial. A análise do líquido peritoneal realizada imediatamente após sua obtenção consistiu em: exames físico (cor, aspecto, volume e densidade); bioquímicos ( $\mathrm{pH}$, proteína total, fibrinogênio, creatinina e glicose); e da celularidade (contagens total e diferencial). A determinação de proteínas e o exame da celularidade foram repetidos, em cada alíquota separada, as duas, quatro, seis e oito horas após a colheita. Análise de variâncias de medidas repetidas ou teste de Friedman foram empregados para avaliação ao longo do tempo. A colheita foi produtiva em $67 \%$ dos bovinos e os locais de punção craniais esquerdo e direito foram os mais adequados. A concentração de proteína total variou de 1,4 a $3,6 \mathrm{~g} / \mathrm{dL}$ e o número de leucócitos de 54 a 1.322 células/ $\mu \mathrm{L}$, com predomínio de linfócitos ( 60 a $95 \%$ das células) no fluido peritoneal analisado logo após a colheita. A concentração de proteínas diminuiu, mas os valores absolutos de leucócitos, de linfócitos e de neutrófilos segmentados não se modificaram até oito horas após a colheita, independente do método de manutenção das amostras. A lise celular foi retardada pela refrigeração e a adição de formol não contribuiu para preservar a integridade da morfologia celular. A laparocentese é um procedimento seguro e de execução fácil em bovinos sendo mais produtiva quando realizada em locais específicos à esquerda ou à direita craniais da parede abdominal. Amostras de fluido peritoneal podem ser analisadas com resultados confiáveis quando mantidas refrigeradas por até oito horas após a colheita e quando mantidas à temperatura ambiente por até seis horas.

TERMOS DE INDEXAÇÃO: Fluido peritoneal, bovinos sadios, morfologia celular, laparocentese, líquido peritoneal, viabilidade celular, conservação.

\section{INTRODUCTION}

Peritoneal fluid analysis is useful for confirming the diagnosis of some conditions affecting the abdominal cavity (Hirsch \& Townsend 1982, Divers \& Peek 2008). Conditions such as peritonitis, uroperitoneum, hemoperitoneum, abdominal neoplasms, gastric, abomasal or intestinal ischemia, or rupture can determine physical, biochemical, and cellular changes in the peritoneal fluid that, when characteristic, allow the diagnosis to be completed (Oehme \& Noordsy 1970, Wilson et al. 1985, Bohn \& Callan 2007). Due to its unquestionable importance, the practice of collecting and examining peritoneal fluid is routinely performed in equine medicine. However, it is not commonly adopted by practitioners in bovine medicine.
Unlike the ease with which peritoneal fluid is harvested from horses, whose laparocentesis site is the midline at the lowest point of the abdomen (Larkin 1994), collecting samples from cattle is more complicated and this discourages the procedure. In cattle, the anatomical arrangement of forestomachs and abomasum allows fluid to accumulate in specific cavity sites (Dirksen 1993). Besides, pathological processes, notably peritonitis, are usually localized in this species (Fecteau 2005, 2009). As a result, the specimen collected from a single puncture site may not reflect disease elsewhere in the abdomen, leading to the need to perform laparocentesis at more than one predefined site (Kopcha \& Schultze 1991b).

Analyses such as cell count and biochemical determination and evaluation of cell morphology need to be performed in the laboratory. This is another difficulty faced by the veterinarian who works in the field; the collected sample must be stored correctly, from its collection to its arrival in the laboratory, in order to preserve its characteristics. Refrigeration is a usual method used for sample conservation, but it does not prevent cells from degenerating (Larkin 1994). The length of cell viability in peritoneal fluid collected from cattle is unknown but assumed to be short (Oehme \& Noordsy 1970, Hirsch \& Townsend 1982, Wilson et al. 1985). Identifying effective methods that can prolong cell preservation is of practical importance.

In order to encourage the adoption of the procedure in cattle, this study aimed to evaluate possible laparocentesis sites suitable for obtaining peritoneal fluid and to establish the duration of cell viability in vitro, comparing conservation methods.

\section{MATERIALS AND METHODS}

Twenty-one healthy crossbred cattle (Bos taurus $\mathrm{x}$ Bos indicus) aged from 1.5 to 6 years old, 2 males and 19 females, were used in this study. All animals belonged to the herd of the Veterinary Teaching Hospital of the "Universidade Estadual de Londrina", which were kept in a semi-confinement system, received sorghum silage as their primary food, and had free access to water and mineral salt.

Laparocentesis was performed in each of the cattle at three defined sites: a) left cranial: in the reticular-ruminal recess, 5 to $6 \mathrm{~cm}$ cranial and medial to the left mammary vein foramen (House 1992); b) right cranial: in the region of the abomasum, at the midpoint between the navel and the xiphoid appendix and to the right of the ventral midline, at the midpoint between this and the right mammary vein (Radostits et al. 2007); c) right caudal: medial to the fold of the right flank in a cranio-dorsal position to the udder (House 1992).

For the procedure, the animals were contained in individual trunks and kept in a quadrupedal position. The puncture sites were previously prepared with trichotomy and antisepsis with iodized alcohol. For the anesthetic button, 2\% lidocaine without vasoconstrictor (Lidovet; Laboratório Bravet Ltda.) was used in a volume of 1 to $2 \mathrm{~mL}$, with deposition in the subcutaneous space and adjacent muscles. Peritoneal fluid was collected 10 minutes after anesthetic application, using a previously sterilized $80 \times 15 \mathrm{~mm}$ metal needle (BD; Becton, Dickinson Indústrias Cirúrgicas Ltda.). After perforation of the skin, abdominal muscles, and peritoneum, the needle mandrel was removed to allow peritoneal fluid to be harvested. For greater safety in performing this procedure, the needle body was kept fixed between the index and thumb fingertips and the mandrel was kept resting on the palm of the hand during 
the puncture; this reduced the risk of sudden needle insertion and perforation of internal organs, such as the reticulum, abomasum, and intestinal loops.

Vacuum collection $5 \mathrm{~mL}$ tubes containing ethylenediaminetetraacetic acid (EDTA) were used to receive the sample obtained from each puncture site. At the time of collection, the volume of fluid obtained from each site was measured. The samples were then combined into a single test tube to obtain a composite sample with total of all collection points.

Immediately after peritoneal fluid collection, blood was collected by jugular vein puncture, using a vacuum $5 \mathrm{~mL}$ tube containing EDTA for subsequent determination of total protein, fibrinogen, and creatinine in plasma.

The first peritoneal fluid analysis was performed immediately after collection. Then, the original total volume was divided into three aliquots, which were kept under different storage conditions: a) kept on the bench at room temperature $\left(26^{\circ} \mathrm{C}\right)$; (b) kept refrigerated $\left.\left(4^{\circ} \mathrm{C}\right) ; \mathrm{c}\right)$ maintained at room temperature $\left(26^{\circ} \mathrm{C}\right)$ with the addition of $1 \mu \mathrm{L}$ of $10 \%$ formaldehyde to each $1 \mathrm{~mL}$ of peritoneal fluid.

Peritoneal fluid was analyzed at five moments after collection: immediately after and two, four, six, and eight hours later. Immediately after collection and before dividing the fluid into three aliquots, full analysis was performed; this included physical examination (color, appearance, and specific gravity), cellular examination (total cell count and differential leukocyte counts), and biochemical tests ( $\mathrm{pH}$, total protein, fibrinogen, glucose, and creatinine). At other times, the analysis consisted of total protein determinations and cellular examination.

The $\mathrm{pH}$ was determined by using indicator strips ( $\mathrm{pH}$-Indicator Strips; Merck, Germany). Specific gravity and total protein were measured by refractometry (Model 301 Manual Refractometer; Biobrix) and fibrinogen concentration was measured by using the heat precipitation method (Kaneko \& Smith 1967). Creatinine and glucose concentrations were measured by colorimetric analysis using specific commercial reagents (Bioclin; Quibasa Química Básica Ltda), with spectrophotometric reading (Bio 2000/Plus; BioTécnica Indústria e Comércio Ltda). Total cell count was performed in a Fuchs-Rosenthal chamber. The total value of nucleated and red blood cells counted in the chamber was divided by three so that the obtained value was expressed in number of cells/ $\mu \mathrm{L}$. For differential counting, one drop of non-centrifuged liquid was deposited on a slide, and the smear was then prepared.

The smear was air dried and stained with Romanowsky stain (Instant Prov; Newprov Produtos para Laboratório Ltda). Differential cell counting was performed by light microscopy. The cellular and structural evaluated characteristics, as criteria of maintenance or not of cellular integrity, were: a) cytoplasmic membrane integrity; b) cell lysis, characterized by the extravasation of its content and fragmentation of organelles; c) presence of cytoplasmic vacuoles; d) nuclear membrane integrity; e) chromatin fragmentation (Curtin et al. 2002, Meinkoth et al. 2009). At least 50 fields were examined in each smear. The observed changes were classified into the following categories according to the percentage of cells that exhibited each change: 0 ) up to $5 \%$ of the affected cells; 1 ) from 6 to $25 \%$ of the affected cells; 2) from 26 to $50 \%$ of the affected cells; 3) from 50 to $75 \%$ of the affected cells.

Repeated measures ANOVA was used to evaluate the variation of total protein concentration in peritoneal fluid over time, using the Tukey test for multiple comparisons. For absolute leukocyte, neutrophil, and lymphocyte values, the Friedman test was used. For these evaluations, each conservation method adopted for sample maintenance was considered separately. The probability of a $5 \%$ error was assumed. SigmaStat for Windows 3.1 was used for the analysis.

\section{RESULTS AND DISCUSSION}

Laparocentesis was productive in 14 (67\%) and unproductive in 7 (33\%) cattle, with successful harvesting at the left (43\% successful) and right (62\% successful) cranial puncture sites (Table 1). Because of the difficulty in collecting peritoneal fluid from the right caudal puncture site (82\% failure), attempts were performed only on the first 11 cattle.

The volume of peritoneal fluid obtained from the left and right cranial puncture sites was mostly equal to or greater than $5 \mathrm{~mL}$. This was more than enough for the routine laboratory test. Of the 13 cattle whose samples were collected from these cranial puncture sites, $8(62 \%)$ had high peritoneal fluid volumes at both collection sites.

The results contradict claims that obtaining peritoneal fluid is difficult in cattle and that harvesting can be unproductive in many animals (House et al. 1992, Larkin 1994, Bohn \& Callan 2007, Radostits et al. 2007). These statements serve to discourage clinicians from performing the procedure, depriving themselves of valuable information for completing the diagnosis of peritonitis. Contrary to the concept that the fluid volume is reduced in the abdomen of healthy cattle and this makes it difficult to collect (Hirsch \& Townsend 1982, Wilson et al. 1985, Fecteau 2005, Divers \& Peek 2008), the harvest was successful in most of the cattle used in this

Table 1. Results of the punctures performed in three different sites of the abdominal wall of healthy cattle $(n=21)$, indicating the volume of peritoneal fluid obtained

\begin{tabular}{cccc}
\hline Cattle & Left cranial & Right cranial & Right caudal \\
\hline 1 & $3.5 \mathrm{~mL}$ & $>5 \mathrm{~mL}$ & $1 \mathrm{~mL}$ \\
2 & $>5 \mathrm{~mL}$ & $>5 \mathrm{~mL}$ & Drops \\
3 & 0 & 0 & Drops \\
4 & Drops of blood & 0 & Drops \\
5 & Drops & $1.3 \mathrm{~mL}$ & Drops \\
6 & Drops of blood & 0 & $>5 \mathrm{~mL}$ \\
7 & 0 & Drops & Drops \\
8 & 0 & 0 & Drops \\
9 & $>5 \mathrm{~mL}$ & $3 \mathrm{~mL}$ & Drops of blood \\
10 & 0 & 0 & Drops of blood \\
11 & Drops & $1 \mathrm{~mL}$ & 0 \\
12 & $0.5 \mathrm{~mL}$ & $5 \mathrm{~mL}$ & Not collected \\
13 & Drops & 0 & Not collected \\
14 & $>5 \mathrm{~mL}$ & $>5 \mathrm{~mL}$ & Not collected \\
15 & $5 \mathrm{~mL}$ & $>5 \mathrm{~mL}$ & Not collected \\
16 & Drops & $5 \mathrm{~mL}$ & Not collected \\
17 & $>5 \mathrm{~mL}$ & $>5 \mathrm{~mL}$ & Not collected \\
18 & 0 & $>5 \mathrm{~mL}$ & Not collected \\
19 & Drops & 0 & Not collected \\
20 & $5 \mathrm{~mL}$ & $>5 \mathrm{~mL}$ & Not collected \\
21 & $>5 \mathrm{~mL}$ & $>5 \mathrm{~mL}$ & Not collected
\end{tabular}


study despite them being healthy. In the clinical routine, the collection will be performed in suspected cases of peritonitis and in the initial phase of this condition the volume of exudate in the cavity is expected to increase, facilitating the collection (Oehme 1969, Wilson et al. 1985).

The presence of peritoneal fluid in the two cranial puncture sites can be explained by the gravitational effect generating its accumulation on the cavity floor, even under physiological conditions. The difficulty of harvesting at the right caudal puncture site, on the other hand, can be justified precisely because the cattle were healthy. This collection site is particularly recommended in cases of diffuse peritonitis, which are accompanied by omental bursitis, in which case the large exudate is sequestered within the space formed by the larger inflamed omentum, permeating the intestinal loops (Fecteau 2005). Therefore, in the studied healthy cattle, there was no accumulation of peritoneal fluid in this cavity site.

Regarding the adopted technique, it should be noted that obtaining peritoneal fluid samples was facilitated when the needle was left free after puncturing the cavity and removing the mandrel. Most of the time, the liquid did not flow immediately. However, the natural movement of the needle, resulting from reticular or abomasum contractions, precipitated spontaneous fluid outflow, dripping, or continuous flow, in variable volumes. Manual movements of the needle for repositioning and the effect of negative pressure produced by the plunger pull of a needle coupled to a syringe did not facilitate harvesting in the studied cattle.

Puncture accidents occurred in four cattle at the first harvest attempt; these accidents were two perforations of the reticulum and two of the abomasum. In these cases, the needle was immediately removed and replaced with a sterile one, and a new cavity puncture was performed at another location near the first one. In three of these cattle, the second harvest attempt was successful. None of them presented apparent later complications, remaining healthy and with a good appetite. The absence of problems related to accidental perforation of the viscera is cited as common in cattle (Wilson et al. 1985, Bohn \& Callan 2007).

The physical, biochemical, and cytological characteristics of the peritoneal fluid obtained from the studied cattle (Table 2) were broadly compatible with those reported for healthy cattle (Hirsch \& Townsend 1982, Dirksen 1993). Light yellow color and slightly cloudy appearance were the predominant findings. Specific gravity ranged from 1010 to 1020 and pH from 7.0 to 8.0, consistent with the health status of cattle (Fecteau 2005, Bohn \& Callan 2007). Total protein concentration ranged from 1.4 to $3.6 \mathrm{~g} / \mathrm{dL}$ and can be considered physiological. Although there is some divergence as to the reference values for this variable, the vast majority of authors admit that protein concentration should be less than or equal to 3g/dL (Kopcha \& Schultze 1991b, Belknap \& Navarre 2000, Fecteau 2005, Bohn \& Callan 2007). Fibrinogen concentration in the fluid did not exceed $200 \mathrm{mg} / \mathrm{dL}$ and was within the accepted reference range for the species (between 100 and 400mg/dL) (Wilson et al. 1985), almost half of its plasma concentration (Table 2). Finally, creatinine concentration in the peritoneal fluid was close to that in the plasma, something that is expected in healthy cattle (Kopcha \& Schultze 1991b, Bohn \& Callan 2007).

Table 2. Physical, biochemical, and cytological characteristics of peritoneal fluid from healthy cattle ( $\mathrm{n}=14)$, examined shortly after collection and some plasma variables in samples collected shortly after laparocentesis

\begin{tabular}{|c|c|c|c|c|c|}
\hline & $\mathrm{x}$ & s & Md & Minimum & Maximum \\
\hline \multicolumn{6}{|l|}{ Peritoneal fluid } \\
\hline Color & \multicolumn{5}{|c|}{ Light yellow predominant $(n=11)$ and occasional orange $(n=3)$} \\
\hline Aspect & \multicolumn{5}{|c|}{ Slightly cloudy predominant $(n=9)$ and occasional cloudy $(n=5)$} \\
\hline Specific gravity & $1,014.5$ & 3.2 & 1,015 & 1,010 & 1,020 \\
\hline pH & 7.22 & 0.40 & 7.0 & 7.0 & 8.0 \\
\hline Total protein $(\mathrm{g} / \mathrm{dL})$ & 2.1 & 0.6 & 2.0 & 1.4 & 3.6 \\
\hline Fibrinogen (mg/dL) & 112.5 & 34.1 & 100 & 100 & 200 \\
\hline Glucose (mg/dL) & 55.9 & 5.4 & 55.3 & 48.7 & 66.6 \\
\hline Creatinine (mg/dL) & 1.3 & 0.4 & 1.2 & 0.7 & 2.2 \\
\hline Leukocytes $(/ \mu \mathrm{L})$ & 1,079 & 977 & 896 & 54 & 1,322 \\
\hline Segmented neutrophils (\%) & 15.2 & 9.3 & 14.0 & 5 & 40 \\
\hline Lymphocytes (\%) & 84.7 & 9.4 & 86.0 & 60 & 95 \\
\hline Segmented neutrophils $(/ \mu \mathrm{L})$ & 182 & 230 & 127 & 4 & 303 \\
\hline Lymphocytes $(/ \mu \mathrm{L})$ & 921 & 862 & 767 & 50 & 1,065 \\
\hline
\end{tabular}

\section{Plasma}

Total protein $(\mathrm{g} / \mathrm{dL})$

Fibrinogen $(\mathrm{mg} / \mathrm{dL})$

Creatinine $(\mathrm{mg} / \mathrm{dL})$
0.6

89,4

0.4 
The number of leukocytes varied widely (from 54 to 1,322 cells $/ \mu \mathrm{L}$ ), but can be considered physiological. As indicated in the literature, healthy cattle may have leukocyte counts from $\leq 5,000$ cells $/ \mu \mathrm{L}$ (Anderson et al. 1994) up to $\leq 10,000$ cells $/ \mu \mathrm{L}$ (House et al. 1992, Belknap \& Navarre 2000). Lymphocytes were the predominant cells and represented 60 to $95 \%$ of them, followed by segmented neutrophils that represented 5 to $40 \%$ of the present cells. Eosinophils, basophils, and macrophages were not observed in this study and mesothelial cells were infrequently present and in small numbers. The results are consistent with those reported in healthy cattle (Oehme 1969, Oehme \& Noordsy 1970), but contradict the claim that lymphocytes may be present in as few as $20 \%$ of leukocytes (Wilson et al. 1985, Anderson et al. 1994). For segmented neutrophils, percentages greater than $40 \%$ may be considered as indicative of bovine peritonitis (Wilson et al. 1985, House et al. 1992). The median ratio between mononuclear cells and polymorphonuclear cells observed in the studied cattle was 6:1, unlike the $1: 1$ ratio previously reported for healthy cattle (Oehme \& Noordsy 1970, Bohn \& Callan 2007). Finally, evidence that eosinophils may be present in larger numbers in the peritoneal fluid of healthy cattle, representing up to almost half of all cells (Wilson et al. 1985, Anderson et al. 1994), was not reinforced in the present study.

Peritoneal fluid from healthy animals should contain little or no red blood cells (Wilson et al. 1985, Stockham \& Scott 2011). When present, red blood cells indicate abdominal hemorrhage (hemoperitoneum) or peripheral blood loss resulting from an accident during puncture (Kopcha \& Schultze 1994a). In the studied cattle, the number of red blood cells in the peritoneal fluid ranged from a minimum of $85 / \mu \mathrm{L}$ to a maximum of $18,346 / \mu \mathrm{L}$, with a median of $1,461 / \mu \mathrm{L}$. This high number of red blood cells could be attributed to the accidental puncture of blood vessels during the laparocentesis procedure.

With respect to the changes that were observed in the peritoneal fluid over eight hours after collection, protein concentration decreased $(\mathrm{p}<0.05)$, but absolute leukocyte values, lymphocytes, and segmented neutrophils did not change $(p>0.05)$ (Table 3). The method used for preserving the samples did not interfere with the results and cooling was not better than room temperature maintenance. Even the reduction in protein concentration detected four or six hours after harvest was very slight and may be considered insufficient to compromise the interpretation of the results. Therefore, it may be assumed that, regarding these variables, bovine peritoneal fluid presented reliable results when processed up to eight hours after its collection, even if it was not kept refrigerated. This contradicts the recommendations that the sample should be examined as soon as possible after collection (Oehme 1969) or that it should be kept refrigerated for storage (Oehme \& Noordsy 1970, Hirsch \& Townsend 1982). Some reports indicate that the refrigerated peritoneal fluid sample can be examined, with reliable results, up to 18 hours after collection (Wilson et al. 1985).

Regarding the evaluated criteria indicating cell integrity maintenance, it should be noted that the irregularity or rupture of the cytoplasmic membrane and cell lysis were the important changes observed; the irregularity or rupture of the nuclear membrane and the chromatin fragmentation were uncommon alterations, while cytoplasmic vacuoles were rarely present. The irregularity or rupture of the cytoplasmic membrane and cell lysis were already present since the first peritoneal fluid analysis, performed immediately after its

Table 3. Mean values $(\mathrm{x} \pm \mathrm{s})$ of protein concentrations and median values of leukocytes in healthy bovine peritoneal fluid samples $(n=12)$, maintained for up to eight hours after collection under different conditions: room temperature at $26^{\circ} \mathrm{C}(\mathrm{RT})$; refrigeration at $4^{\circ} \mathrm{C}(\mathrm{R})$; room temperature at $26^{\circ} \mathrm{C}$ with the addition of formaldehyde (RTF)

\begin{tabular}{|c|c|c|c|c|c|}
\hline & $0 \mathrm{~h}$ & $2 \mathrm{~h}$ & $4 \mathrm{~h}$ & $6 \mathrm{~h}$ & $8 \mathrm{~h}$ \\
\hline \multicolumn{6}{|c|}{ Proteins (g/dL) } \\
\hline RT & $1.95 \pm 0.45^{\mathrm{a}}$ & $1.91 \pm 0.48^{\mathrm{ab}}$ & $1.88 \pm 0.49^{\mathrm{ab}}$ & $1.86 \pm 0.49^{b}$ & $1.84 \pm 0.50^{\mathrm{b}}$ \\
\hline $\mathrm{R}$ & $1.95 \pm 0.45^{\mathrm{a}}$ & $1.91 \pm 0.48^{\mathrm{ab}}$ & $1.88 \pm 0.49^{\mathrm{b}}$ & $1.88 \pm 0.49^{b}$ & $1.85 \pm 0.51^{\mathrm{b}}$ \\
\hline RTF* $^{*}$ & $1.95 \pm 0.45^{\mathrm{a}}$ & $1.91 \pm 0.48^{\mathrm{ab}}$ & $1.88 \pm 0.49^{\mathrm{b}}$ & $1.88 \pm 0.49^{\mathrm{b}}$ & $1.85 \pm 0.51^{\mathrm{b}}$ \\
\hline \multicolumn{6}{|c|}{ Leukocytes $(/ \mu \mathrm{L})$} \\
\hline RT & $901^{\mathrm{a}}$ & $880^{\mathrm{a}}$ & $816^{\mathrm{a}}$ & $826^{a}$ & $858^{\mathrm{a}}$ \\
\hline $\mathrm{R}$ & $901^{\mathrm{a}}$ & $880^{\mathrm{a}}$ & $805^{a}$ & $1,066^{\mathrm{a}}$ & $944^{\mathrm{a}}$ \\
\hline $\mathrm{RTF}^{*}$ & $901^{\mathrm{a}}$ & $869^{\mathrm{a}}$ & $896^{\mathrm{a}}$ & $1,002^{\mathrm{a}}$ & $1,002^{\mathrm{a}}$ \\
\hline \multicolumn{6}{|c|}{ Segmented neutrophils $(/ \mu \mathrm{L})$} \\
\hline RT & $127^{\mathrm{a}}$ & $109^{\mathrm{a}}$ & $163^{\mathrm{a}}$ & $66^{\mathrm{a}}$ & $118^{\mathrm{a}}$ \\
\hline $\mathrm{R}$ & $127^{\mathrm{a}}$ & $148^{\mathrm{a}}$ & $89^{a}$ & $134^{\mathrm{a}}$ & $124^{\mathrm{a}}$ \\
\hline $\mathrm{RTF}^{*}$ & $127^{\mathrm{a}}$ & $151^{\mathrm{a}}$ & $128^{\mathrm{a}}$ & $118^{\mathrm{a}}$ & $118^{\mathrm{a}}$ \\
\hline \multicolumn{6}{|c|}{ Lymphocytes $(/ \mu \mathrm{L})$} \\
\hline RT & $856^{\mathrm{a}}$ & $674^{\mathrm{a}}$ & $591^{\mathrm{a}}$ & $715^{\mathrm{a}}$ & $670^{\mathrm{a}}$ \\
\hline $\mathrm{R}$ & $856^{\mathrm{a}}$ & $752^{\mathrm{a}}$ & $653^{a}$ & $783^{a}$ & $771^{\mathrm{a}}$ \\
\hline RTF* & $856^{a}$ & $741^{\mathrm{a}}$ & $774^{\mathrm{a}}$ & $832^{\mathrm{a}}$ & $863^{\mathrm{a}}$ \\
\hline
\end{tabular}

*10\% formaldehyde: $1 \mu \mathrm{L}$ for each $1 \mathrm{~mL}$ of peritoneal fluid; ${ }^{\text {a,b }}$ different letters indicate statistical difference $(\mathrm{p}<0.05)$. 
collection. At this time, however, the number of affected cells was small. Overall, time elapsed after harvesting increased the percentage of cells exhibiting these two changes (Table 4).

The percentage of cells with irregular or ruptured cytoplasmic membranes increased four hours after collection in the samples in which formaldehyde was added and, apparently, eight hours after collection in those that did not receive formaldehyde. Refrigeration did not delay the appearance of this change in the cells. Cell lysis, in turn, increased six hours after collection and intensified eight hours after collection in samples that were kept uncooled. It can be stated that refrigeration substantially minimized the occurrence of this type of change (Table 4). The observed changes occurred earlier in segmented neutrophils than in lymphocytes, indicating that neutrophils are more susceptible to in vitro adverse conditions, and maintain their integrity for a shorter time outside the body (Stockham \& Scott 2011).

It is reasonable to assume that the evaluation of cells for differential counting will not be compromised if the morphological changes that cells experience in vitro affect only up to a quarter of them. This motivated the definition of this limit in the present study (Table 4). It should also be noted that, among the observed alterations, cell lysis is the one that, in fact, impairs the cytological evaluation; while the

Table 4. Changes observed in leukocytes in healthy bovine peritoneal fluid samples $(n=12)$, maintained for up to eight hours after collection under different conditions: room temperature at $26^{\circ} \mathrm{C}(\mathrm{RT})$; refrigeration at $4^{\circ} \mathrm{C}(\mathrm{R})$; room temperature at $26^{\circ} \mathrm{C}$ with the addition of formaldehyde (RTF). Results expressed as the percentage of samples examined with changes present in up to a maximum of $25 \%$ of cells

\begin{tabular}{|c|c|c|c|c|c|}
\hline & $0 \mathrm{~h}$ & $2 \mathrm{~h}$ & $4 \mathrm{~h}$ & $6 \mathrm{~h}$ & $8 \mathrm{~h}$ \\
\hline \multicolumn{6}{|c|}{ Cytoplasmic membrane irregularity or rupture } \\
\hline RT & 90 & 78 & 90 & 80 & 70 \\
\hline $\mathrm{R}$ & 90 & 80 & 81 & 72 & 70 \\
\hline RTF* & 90 & 77 & 60 & 50 & 66 \\
\hline \multicolumn{6}{|c|}{ Cell lysis } \\
\hline RT & 81 & 88 & 90 & 70 & 60 \\
\hline $\mathrm{R}$ & 81 & 80 & 100 & 90 & 90 \\
\hline $\mathrm{RTF}^{*}$ & 81 & 88 & 90 & 70 & 55 \\
\hline \multicolumn{6}{|c|}{ Cytoplasmic vacuoles } \\
\hline RT & 100 & 100 & 100 & 100 & 100 \\
\hline $\mathrm{R}$ & 100 & 100 & 100 & 100 & 100 \\
\hline RTF* & 100 & 100 & 100 & 100 & 100 \\
\hline \multicolumn{6}{|c|}{ Nuclear membrane irregularity or rupture } \\
\hline RT & 100 & 100 & 100 & 100 & 100 \\
\hline $\mathrm{R}$ & 100 & 100 & 100 & 100 & 100 \\
\hline RTF* & 100 & 100 & 100 & 100 & 100 \\
\hline \multicolumn{6}{|c|}{ Fragmented chromatin } \\
\hline RT & 100 & 100 & 100 & 100 & 100 \\
\hline $\mathrm{R}$ & 100 & 100 & 100 & 100 & 100 \\
\hline RTF* & 100 & 100 & 100 & 100 & 100 \\
\hline
\end{tabular}

* $10 \%$ formaldehyde: $1 \mu \mathrm{L}$ for each $1 \mathrm{~mL}$ of peritoneal fluid. irregularity or rupture of the cytoplasmic membrane creates difficulty for the examination, it does not always prevent the cell type to be defined by the examiner. Thus, the observed results reinforce the notion that refrigeration is the recommended conservation method and bovine peritoneal fluid can be analyzed with reliable results up to eight hours after harvest. Even in samples that have not been kept refrigerated, the test result can be reliable up to four or six hours after collection. Finally, it is clear that the addition of formaldehyde for the purpose of cell preservation is not justified because it does not fulfill its purpose.

One should not ignore the fact that the evaluated peritoneal fluid samples were from healthy cattle, therefore, they were transudates. It is likely that, in the case of exudates, the time to maintain cell viability is shorter than that observed in the present study. This statement is justified due to the presence of proteases, cytokines, and inflammation mediators (Kopcha \& Schultze 1991a), in addition to the larger number of segmented neutrophils, which could be more reactive or already in a frank degeneration process (Rizzi et al. 2009). In cases of peritonitis, the main condition that justifies the collection and analysis of peritoneal fluid in cattle, in vitro conditions would be much more adverse than those present in this study. For this reason, it is logical to indicate that the sample taken must be kept under refrigeration.

\section{CONCLUSIONS}

Laparocentesis is a safe and easily performed procedure in cattle and peritoneal fluid collection is successful when puncture is performed at two specific points of the ventral abdominal wall: in the left cranial situation, corresponding to the space of the reticular recess and in the right cranial situation, corresponding to the ventral space of the abomasum at the lowest point of the abdomen.

After collection, peritoneal fluid from healthy cattle can be examined with reliable results for up to eight hours if kept refrigerated and for up to six hours if kept at room temperature. Refrigeration delays the degenerative process that cells experience in vitro, thus increasing cell viability.

This method should be used to preserve specimens during transport when peritonitis is suspected. Because of the ease, safety, and practicality involved, clinicians could adopt this diagnostic procedure whenever they suspect diseases located in the abdominal cavity. The distance to the laboratory cannot be considered a hindrance and pointed as justification for not performing the method.

Acknowledgements.- Júlio A.N. Lisbôa is recipient of "Conselho Nacional de Desenvolvimento Científico e Tecnológico" (CNPq) fellowship.

Conflict of interest statement.- We have no conflict of interest to declare.

\section{REFERENCES}

Anderson D.E., Cornwell D., St-Jean G., Desrochers A. \& Anderson L.S. 1994. Comparison of peritoneal fluid analysis before and after exploratory celiotomy and omentopexy in cattle. Am. J. Vet. Res. 55(12):1633-1637.

Belknap E.B. \& Navarre C.B. 2000. Differentiation of gastrointestinal disease in adult cattle. Vet. Clin. N. Am., Food Anim. Pract. 16(1):59-86.

Bohn A.A. \& Callan R.J. 2007. Cytology in food animal practice. Vet. Clin. N. Am., Food Anim. Pract. 23(3):443-479. 
Curtin J.F., Donovan M. \& Cotter T.G. 2002. Regulation and measurement of oxidative stress in apoptosis. J. Immunol. Methods 265(1):49-72.

Dirksen G. 1993. Sistema digestivo, p.166-228. In: Dirksen G., Gründer H.D \& Stöber M. (Eds), Rosenberger, Exame clínico dos bovinos. $3^{\underline{a}}$ ed. Guanabara Koogan, Rio de Janeiro.

Divers T.J. \& Peek S.F. 2008. Therapeutics and routine procedures. p.1640. In: Ibid. (Eds), Rebhun's Diseases of Dairy Cattle. 2nd ed. Saunders Elsevier, St Louis.

Fecteau G. 2005. Management of peritonits in cattle. Vet. Clin. N. Am., Food Anim. Pract. 21(1):155-171.

Fecteau G. 2009. Peritonitis in ruminant, p.850-855. In: Smith B.P. (Ed.), Large Animal Internal Medicine. 4th ed. Mosby Elsevier, Saint Louis.

Hirsch V.M. \& Townsend H.G.G. 1982. Peritoneal fluid analysis in the diagnosis of abdominal disorders in cattle: a retrospective study. Can. Vet. J. 23(12):348-354.

House J.K., Smith B.P., VanMetre D.C., Fecteau G., Craychee T. \& Neves J. 1992. Ancillary testes for assessment of the ruminant digestive system. Vet. Clin. N. Am., Food Anim. Pract. 8(2):203-232.

Kaneko J.J. \& Smith R. 1967. The estimation of plasma fibrinogen and its clinical significance in the dog. California Vet. 21(4):21-24.

Kopcha M. \& Schultze A.E. 1991a. Peritoneal fluid. Part I. Pathophysiology and classification of nonneoplastic effusions. Compend. Contin. Educ. Pract. Vet. 13(3):519-525.
Kopcha M. \& Schultze A.E. 1991b. Peritoneal fluid. Part II. Abdominocentesis in cattle and interpretation of nonneoplastic samples. Compend. Contin. Educ. Pract. Vet. 13(4):703-709.

Larkin H.A. 1994. Veterinary cytology: collection and examination of body cavity fluids in animals. Irish Vet. J. 47(2):211-219.

Meinkoth J.H., Cowell R.L. \& Tyler R.D. 2009. Tipos celulares e critérios de malignidade, p.20-46. In: Cowell R.L., Tyler R.D., Meinkoth J.H. \& DeNicola D.B. (Eds), Diagnóstico Citológico e Hematologia de Cães e Gatos. 3aa ed. MedVet, São Paulo.

Oehme F.W. 1969. Cytologic examination of peritoneal fluid in the diagnosis of cattle disease. J. Am. Vet. Med. Assoc. 155(12):1923-1927.

Oehme F.W. \& Noordsy J.L. 1970. Examination of peritoneal fluid in differential diagnosis of bovine diseases. Vet. Med., Small Anim. Clin. 65(1):54-59.

Radostits O.M., Gay C.C., Hinchcliff K.W. \& Constable P.D. 2007. Diseases of the alimentary tract II, p.293-382. In: Ibid. (Eds), Veterinary Medicine: a textbook of the disease of cattle, horses, sheep, pigs and goats. 10th ed. Saunders Elsevier, Edinburgh.

Rizzi T.E., Cowell R.D., Tyler R.D. \& Meinkoth J.H. 2009. Efusões: abdominal, torácica e pericárdica, p.235-255. In: Cowell R.L., Tyler R.D., Meinkoth J.H. \& DeNicola D.B. (Eds), Diagnóstico citológico e hematologia de cães e gatos. 3a ed. MedVet, São Paulo.

Stockham S.L. \& Scott M.A. 2011. Efusões cavitárias, p.688-718. In: Ibid. (Eds), Fundamentos de Patologia Clínica Veterinária. 2a ed. Guanabara Koogan, Rio de Janeiro.

Wilson A.D., Hirsch V.M. \& Osborne A.D. 1985. Abdominocentesis in cattle: technique and criteria for diagnosis of peritonitis. Can. Vet. J. 26(2):74-80. 